\title{
ABSTRAK \\ KORELASI ANTARA KETERAMPILAN METAKOGNITIF DENGAN HASIL BELAJAR BIOLOGI SISWA SMP NEGERI KUPANG
}

Yusnaeni Ganing, Dosen Fakultas Keguruan dan Ilmu Pendidikan, Universitas Nusa Cendana Kupang, J1. Adi Sucipto Penfui Kota Kupang NTT 081339471304, E-mail: yusnaeni_75@yahoo.co.id

\begin{abstract}
Penelitian ini bertujuan untuk mengetahui hubungan antara keterampilan dan dengan hasil belajar biologi siswa SMP negeri di kota Kupang. Penelitian ini adalah penelitian deskripitif dengan metode pengambilan sampel secara survey pada siswa SMP Negeri di Kota Kupang. Pengambilan sampel dilakukan secara acak. Sampel penelitian adalah SMP Negeri 1, 3, dan 4. Data keterampilan metakognitif diperoleh melalui tes essay yang terintegrasi dengan keterampilan metakognitif. Hasil belajar biologi diperoleh langsung dari sekolah sampel. Data yang diperoleh dianalisis dengan statistik inferensial. Hasil penelitian diperoleh bahwa ada korelasi antara keterampilan metakognitif dengan hasil belajar biologi siswa SMP di Kota Kupang.
\end{abstract}

Kata kunci: keterampilan metakognitif, hasil belajar biologi

\section{ABSTRACT \\ KORELASI ANTARA KETERAMPILAN METAKOGNITIF DENGAN HASIL BELAJAR BIOLOGI SISWA SMP NEGERI KUPANG}

\begin{abstract}
This study aims to determinate the relatioship between metacognitive skills by learning outcomes of biology at Junior High School student in the Kupang city. Sampling was done randomly. The samples were SMP Negeri 1, SMP Negeri 3 dan SMP Negeri 4 Kupang. Data metacognitive skills acquired through integrated essay test with metacognitive skill. Biology study result obtained diretcly from data sample school. The result showed that there is a correlation between the metacognitive skills with learning outcomes Junior High School in the Kupang City.
\end{abstract}

Keywords: metacognitive skills, learning outcome of biology

Perkembangan sains dan teknologi serta kemampuan dan mengembangkan

perubahan kondisi masyarakat yang pesat keahlian. Paradigma baru dalam

mengharuskan guru meningkatkan pembelajaran sains menuntut siswa 
memiliki kemampuan berpikir dan kemampuan berpikirnya (Purwanto, bertindak berdasarkan pengetahuan sains 2007). Lebih lanjut, Sobur (2003) juga melalui kerangka berpikir sains. Sains tidak hanya ditandai adanya kumpulan menambahkan bahwa berpikir merupakan fakta, tetapi juga munculnya "metode suatu proses yang mempengaruhi penafsiran terhadap rangsanganilmiah" (scientific methods) yang terwujud rangsangan yang melibatkan proses melalui suatu rangkaian "kerja ilmiah" sensasi, persepsi dan memori. (working scientifically), nilai dan "sikap ilmiah" (scientific attitudes).

Kegiatan pembelajaran yang Berdasarkan hal tersebut, disimpulkan bahwa berpikir adalah suatu kegiatan yang kompleks yang melibatkan kognisi berlangsung di kelas yang selama ini pada seseorang dalam rangka adaptasi terhadap umumnya masih terpusat pada guru perubahan lingkungan. Kemampuan seharusnya sudah digeser ke arah berpusat berpikir seseorang menentukan di siswa sehingga kecenderungan siswa yang menerima materi dari guru tanpa ada kreatifitas dan kemandirian dalam memecahkan suatu persoalan dapat diminimalkan. Demikian pula dengan partisipasi siswa dalam aktivitas pembelajaran yang rendah dapat diatasi. Kurangnya aktivitas dan kreativitas siswa dalam pembelajaran disebabkan kurang memiliki kemampuan untuk mengemukakan gagasan sendiri. Salah satu penyebabnya adalah berhubungan dengan kemampuan berpikir.

Berpikir merupakan daya saing yang paling utama. Kemampuan manusia untuk mempertahankan diri terhadap perubahan lingkungan tergantung pada kemampuan adaptasinya terhadap lingkungan.

Kemampuan berpikir dapat dikembangkan dan diperkaya dengan memperkaya pengalaman-pengalaman yang bermakna dalam proses pembelajaran (Purwanto, 2007). Sementara Tyler (1986), berpendapat bahwa pengalaman atau pembelajaran yang memberikan kesempatan kepada siswa untuk memperoleh keterampilanketerampilan dalam pemecahan masalah akan mewujudkan kemampuan berpikir. Pendapat lain juga dikemukakan oleh Nickerson (1985) yakni kemampuan berpikir selalu berkembang dan dapat dipelajari. Oleh karena itu penulis 
menyimpulkan bahwa untuk kemampuan metakognitif bukanlah hal menumbuhkan kemampuan berpikir, yang sederhana akan tetapi patut dicoba.

siswa perlu dilibatkan dalam pengalaman belajar yang bermakna dalam pembelajaran melalui pemecahan masalah.

Salah satu kemampuan berpikir yang penting bagi siswa adalah kemampuan metakognitif. Dengan siswa memliki kemampuan metakognitif, siswa mengetahui belajar secara sadar. Bila siswa belajar secara sadar tentu akan berbeda maknanya jika dilakukan secara terpaksa. Belajar secara sadar dapat membuat siswa belajar lebih aktif, bergairah dan percaya diri selama proses pembelajaran. Proses pembelajaran yang pelaksanaaanya disertai dengan metakognitif akan memungkinkan peningkatan kesadaran siswa terhadap apa yang dipelajari. Peningkatan kemampuan metakognitif siswa merupakan salah satu efek yang perlu dihasilkan dari pembelajaran. Jika aspek metakognitif dilaksanakan dalam pembelajaran di sekolah maka dapat memfasilitasi kemampuan berpikir metakognitif siswa khususnya dalam mempelajari biologi. Tentu saja menjadikan siswa memiliki 
ini memberikan gambaran bahwa hubungan antara keterampilan komponen penting dari metakognitif metakognitif dengan hasil belajar siswa. adalah kemampuan siswa dalam Populasi penelitian adalah seluruh SMP merefleksikan belajar mereka sendiri. Negeri di Kota Kupang sebanyak 16 Aktivitas metakognitif sebenarnya sekolah. Pengambilan sampel dilakukan merupakan dua proses kognitif mendasar menggunakan teknik sampling purposive yang muncul pada saat ketika seseorang memanfaatkannya. Ketika seseorang memonitoring kemajuan belajarnya, maka pada saat yang sama ia juga mengubah strateginya ketika dia merasa apa yang dilakukannya tidak betul. Bertolak dari uraian di atas yang menunjukkan hubungan erat kemampuan metakognitif dan kemampuan berpikir siswa yang pada akhirnya akan berpengaruh pada hasil belajar siswa. Maka perlu dilihat korelasi antara keterampilan metakognitif dengan hasil belajar biologi siswa SMP di Kota Kupang.

\section{METODE PENELITIAN}

Penelitian ini adalah penelitian korelasi yang ditujukan untuk mencari dengan mengambil tiga sekolah sebagai sampel yaitu SMP Negeri 1, SMP Negeri 3 dan SMP Negeri 4. Variabel bebas adalah adalah keterampilan dan variabel terikat adalah hasil belajar siswa..

Instrumen yang digunakan Tes pemahaman konsep Biologi yang terintegrasi dengan keterampilan metakognisi berbentuk essay. Keterampilan metakognisi mengacu pada rubrik MAD (Corebima, 2008). meliputi: 1) jawaban dalam kalimat sendiri, 2) urutan paparan jawaban runtut, sistematis dan logis, 3) gramatika atau bahasa, 4) alasan (analisis/evaluasi/kreasi) dan 5) jawaban (benar/kurang/tidak benar/kosong). Keterampilan metakognisi ditentukan dengan menggunakan rumus: dimana:

$$
\mathrm{x}=(3 \mathrm{y} 2-\mathrm{y} 1) / 2 \quad \text { (Corebima, 2009) }
$$

y1 = skor pemahaman konsep, $\quad \mathrm{x}=$ skor keterampilan metakognisi. y2 = skor gabungan antara pemahaman konsep dan keterampilan metakognisi

Data penelitian dianalisis dengan menggunakan analisis statistik deskriptif dan statistik inferensial . Statistik deskriptif dilakukan dalam bentuk jumlah, rata-rata dan 
persentase. Statistik inferensial dilakukan untuk menguji hipotesis menggunakan analisis korelasional.

\section{HASIL PENELITIAN}

\section{Hubungan Keterampilan Metakognitif dengan Hasil Belajar Kogitif Siswa}

Hasil uji regresi antara keterampilan metakognitif dengan hasil belajar pada SMP Negeri 4 disajikan pada tabel 1 sedangkan ringkasan Anova hubungan keterampilan metakognitif terhadap hasil belajar disajikan pada tabel 2.

Tabel 1. Ringkasan Regresi Hubungan Keterampilan Metakognitif dengan Hasil Belajar Kognitif Siswa

\begin{tabular}{ccccc}
\hline Model & $\mathbf{R}$ & R Square & $\begin{array}{c}\text { Adjusted R } \\
\text { Square }\end{array}$ & $\begin{array}{c}\text { Std. Error of } \\
\text { the Estimate }\end{array}$ \\
\hline 1 &, $330^{\mathrm{a}}$ &, 109 &, 091 & 5,5600 \\
\hline
\end{tabular}

a. Predictor: (constant), keterampilan metakognisi

Tabel 2. Ringkasan Anova Hubungan antara Keteramplan Metakognitif dengan Hasil Belajar Kognitif Siswa

\begin{tabular}{clccccc}
\hline & Model & Sum of Squares & Df & Mean Square & F & Sig. \\
\hline 1 & Regression & 192,585 & 1 & 192,585 & 6,230 &, $016^{\mathrm{a}}$ \\
\hline & Residual & 1576,585 & 51 & 30,913 & & \\
\hline & Total & 1769,170 & 52 & & & \\
\hline
\end{tabular}

a. Predictor: (constant), keterampilan metakognitif

b. Dependent variable: hasil belajar

Hasil uji rageresi pada tabel 2 diperoleh nilai $F$ sebesar 6,230 dengan nilai signifikan 0,016 $<0,05$. Dengan demikian dapat disimpulkan bahwa ada korelasi antara keterampilan metakognitif dengan hasil belajar kognitif siswa SMP Negeri 4 Kupang.

\section{Hubungan Keterampilan Metakognitif dengan Hasil Belajar Kogitif Siswa}

Hasil uji regresi antara keterampilan metakognitif dengan hasil belajar pada SMP Negeri 1 disajikan pada tabel 3 sedangkan ringkasan Anova hubungan keterampilan metakognitif terhadap hasil belajar disajikan pada tabel 4.

Tabel 3. Ringkasan Regresi Hubungan Keterampilan Metakognitif dengan Hasil Belajar Kognitif Siswa

\begin{tabular}{ccccc}
\hline Model & $\mathbf{R}$ & $\mathbf{R}$ Square & $\begin{array}{c}\text { Adjusted R } \\
\text { Square }\end{array}$ & $\begin{array}{c}\text { Std. Error of } \\
\text { the Estimate }\end{array}$ \\
\hline 1 &, $137^{\mathrm{a}}$ &, 109 &,- 010 & 1,7917 \\
\hline
\end{tabular}

b. Predictor: (constant), keterampilan metakognitif

Tabel 4. Ringkasan Anova Hubungan antara Keteramplan Metakognitif dengan Hasil Belajar Kognitif Siswa

\begin{tabular}{clccccc}
\hline & Model & Sum of Squares & Df & Mean Square & F & Sig. \\
\hline 1 & Regression & 2,079 & 1 & 2,079 & 0,648 &, $427^{\mathrm{a}}$ \\
\hline & Residual & 109,143 & 34 & 3,210 & & \\
\hline Total & 111,222 & 35 & & & \\
\hline \hline
\end{tabular}


a. Predictor: (constant), keterampilan metakognisi

b. Dependent variable: hasil belajar

Hasil uji rageresi pada tabel 4 diperoleh nilai $\mathrm{F}$ sebesar 0,648 dengan nilai signifikan 0,427 >0,05. Dengan demikian dapat disimpulkan bahwa tidak ada korelasi antara keterampilan metakognitif dengan hasil belajar kognitif siswa SMP Negeri 1 Kupang.

\section{Hubungan Keterampilan Metakognitif dengan Hasil Belajar Kogitif Siswa}

Hasil uji regresi antara keterampilan metakognitif dengan hasil belajar pada SMP Negeri 3 disajikan pada tabel 5 sedangkan ringkasan Anova hubungan keterampilan metakognitif terhadap hasil belajar disajikan pada tabel 6 .

Tabel 5. Ringkasan Regresi Hubungan Keterampilan Metakognitif dengan Hasil Belajar Kognitif Siswa.

\begin{tabular}{ccccc}
\hline Model & $\mathbf{R}$ & $\mathbf{R}$ Square & $\begin{array}{c}\text { Adjusted R } \\
\text { Square }\end{array}$ & $\begin{array}{c}\text { Std. Error of } \\
\text { the Estimate }\end{array}$ \\
\hline 1 &, $770^{\mathrm{a}}$ &, 593 &, 585 & 6,9359 \\
\hline
\end{tabular}

c. Predictor: (constant), keterampilan metakognitif

Tabel 6. Ringkasan Anova Hubungan antara Keteramplan Metakognitif dengan Hasil Belajar Kognitif Siswa

\begin{tabular}{clccccc}
\hline & Model & Sum of Squares & Df & Mean Square & F & Sig. \\
\hline 1 & Regression & 3647,953 & 1 & 3647,953 & 75,831 &, $000^{\mathrm{a}}$ \\
\hline & Residual & 2501,529 & 52 & 48,106 & & \\
\hline & Total & 6149,481 & 53 & & & \\
\hline
\end{tabular}

a. Predictor: (constant), keterampilan metakognisi

b. Dependent variable: hasil belajar

Hasil uji rageresi pada tabel 6 diperoleh nilai $F$ sebesar 75,831 dengan nilai signifikan $0,000<0,05$. Dengan demikian dapat disimpulkan bahwa ada korelasi antara keterampilan metakognitif dengan hasil belajar kognitif siswa SMP Negeri 3 Kupang.

\section{PEMBAHASAN}

Hasil analisis statistik diperoleh bahwa dari ada korelasi antara keterampilan metakognitif dengan hasil belajar untuk SMP Negeri 3 dan 4, kegagalan siswa mengingat kembali sedangkan untuk SMP Negeri 1 tidak informasi yang tersimpan dalam ingatan menunjukkan korelasi. Hasil analisis siswa. Hal ini seperti yang diungkap oleh korelasi yang tidak menunjukkan Winkel (2005) bahwa lupa berkaitan hubungan pada SMP Negeri 1 dengan fase penggalian dan fase prestasi kemungkinan disebabkan oleh kurangnya pengawasan pada saat pelaksanaan tes sehingga siswa bebas membuka buku. Disisi lain kemungkinan disebabkan oleh 
yang ada di otak. Lupa menunjukkan kesulitan untuk menggali informasi yang telah diperhatikan, diolah dan dimasukkan ke dalam ingatan jangka panjang. Tapi walaupun demikian secara umum dapat dikatakan bahwa ada korelasi antara keterampilan metakognitif dengan prestasi belajar.

Pada hakekatnya, belajar adalah kegiatan yang bukan sekedar mengingat, melainkan juga melibatkan keterampilan dalam memahami dan menganalisis proses belajar diri sendiri, sehingga informasi yang diperoleh tersimpan dalam memori jangka panjang. Untuk itu diperlukan suatu strategi belajar agar siswa menyadari tentang apa yang telah diketahui dan yang belum diketahui. Hal senada diungkap oleh Nur (2004) bahwa tugas pendidikan tidak hanya menuangkan atau menjejalkan sejumlah informasi ke benak siswa, tetapi mengusahakan bagaimana agar konsep-konsep tertanam kuat dalam benak siswa.

Keterampilan siswa untuk memahami dan mengnalisis proses belajarnya termasuk dalam keterampilan metakognisi. Keterampilan ini sangat dipengaruhi oleh latar belakang pendidikan dan pengalaman sebelumnya.
Keterampilan metakognitif pada dasarnya adalah kesadaran berpikir tentang apa yang diketahui dan apa yang tidak diketahui. Keberhasilan seseorang dalam belajar dipengaruhi oleh kemampuan metakognitifnya. Hal ini didukung oleh hasil penelitian Miranda (2010) yang mengungkap bahwa hasil belajar siswa dapat berkualitas apabila siswa secara sadar mampu mengontrol proses kognitifnya dan berdampak pada kemampuan metakognitif. Demikian pula yang dungkap oleh Djiwandono (2006) bahwa kemampuan metakognitif dapat diberdayakan dengan strategi tertentu agar belajar dan mengingat dapat berkembang.

Keterampilan metakognitif merujuk bagaimana seseorang mengawal pikirannya dengan merancang, memantau dan menilai apa yang dipelajarinya. Keterampilan metakognitif mengacu pada keterampilan perencanaan (planning skills), keterampilan monitoring (monitoring skills), keterampilan evaluasi (evaluating skills) dan keterampilan prediksi (prediction skill) (Livingston, 1997). Keterampilan metakognitif diperlukan untuk memahami bagaimana tugas itu dilaksanakan (Scraw, 1998). Corebima (2010) mengungkap bahwa 
keterampilan metakognitif pada umumnya terbagi atas self assessment atau keterampilan mengakses kognitif sendiri dan self management atau keterampilan mengelola perkembangan kognitif sendiri lebih lanjut. Jika keterampilan metakognitif dikembangkan pada diri siswa maka akan sangat berdampak pada peningkatan hasil belajar siswa. Untuk itu, sangat diperlukan peran seorang guru untuk memunculkan dan mengasah keterampilan ini agar siswa dapat melakukan proses pembelajaran secara sadar.

Peran guru dalam mengembangkan keterampilan metakognitif siswa tidak hanya dalam pengembangan pengajaran metakognitif tapi juga didorong untuk menerapkannya dalam strategi belajar mengajar sehingga dapat memunculkan kemampuan metakognitif siswa. Strategi belajar ini dikenal dengan istilah strategi metakognitif. Malone (2008) menekankan bahwa tujuan strategi metakognitif adalah mendeteksi kesalahan, memberikan usaha dan perhatian, pertanyaan diri, penjelasan diri, membangun pernyataan-pernyataan, mengaktifkan pengetahuan sebelumnya, membuka kembali bacaan teks yang sulit, dan kembali merevisi. Hal in memungkinkan siswa untuk dapat menemukan kesalahan-kesalahan dalam proses berpikir dan hasil pemikirannya tentang suatu pengetahuan yang baru.

Strategi metakognitif digunakan untuk membantu siswa memperoleh kesadaran tentang proses berpikirnya dalam memperoleh suatu informasi. Kemudian informasi yang diperoleh dapat diterapkan dalam permasalahan kehidupan sehari-hari termasuk jika menghadapi permasalahan yang berbeda. Dengan demikian dalam pembelajaran siswa termotivasi dan diberi kesempatan untuk belajar memahami dan mengorganisir informasi yang diterima di kelas.

Jika seseorang sadar tentang apa yang dipikirkan maka akan diperoleh kemudahan untuk memantau tindakan yang diambil. Kesadaran diperlukan untuk meningkatkan pembelajaran. Untuk itulah perlu pembimbingan untuk berpikir. Dengan berpikir, dapat membantu seseorang menyelesaikan masalah dan membuat keputusan. Mengembangkan metakognisi pada dasarnya adalah meningkatkan kemampuan berpikir. Jika kemampuan berpikir senantiasa dikembangkan dan dilatih akan berdampak pada kemampuan akademik 
seseorang. Aktivitas metakognitif sebenarnya merupakan dua proses kognitif mendasar yang muncul pada saat ketika seseorang memanfaatkannya. Ketika seseorang memonitoring kemajuan belajarnya, maka pada saat yang sama ia juga mengubah strateginya ketika dia merasa apa yang dilakukannya tidak betul.

Dengan keterampilan metakognitif, menjadikan siswa sebagai manager atas dirinya sendiri serta menjadi penilai atas pemikiran dan pembelajarannya sendiri. Jika hal ini terus dilakukan siswa maka akan berdampak pada pengembangan kemampuan-kemampuan belajar yang lain.

\section{KESIMPULAN}

Berdasarkan hasil analisis data, maka dapat disimpulkan bahwa ada korelasi antara keterampilan metakognitif siswa SMP Negeri di Kota Kupang dengan hasil belajar biologi siswa.

Ada beberapa saran yang terkait dengan kegiatan belajar mengajar di kelas yang perlu dilakukan oleh guru: (1) jika ingin meningkatkan hasil belajar siswa, guru sebaiknya menerapkan strategi pembelajaran yang dapat meningkatkan keterampilan metakognitif siswa. (2) keterampilan metakognitif dapat menjadikan siswa sebagai pebelajar mandiri, (3) Kesadaran guru sebagai motivator dan fasilitator sangat diperlukan dalam mengembangkan keterampilan metakognitif siswa agar hasilnya lebih efektif .

\section{DAFTAR RUJUKAN}

Anderson, I.W. \& Krathwohl, D. R. 2001. A Taxonomy for Learning, Teaching and Assessing: A Review of Bloom's Taxonomy of Educational Objective. United State: Addison Wesley Longman, Inc.

Corebima, A. D. 2008. Rubrik Keterampilan Metakognisi yang Terintegrasi dengan Tes Essay, Rubrik MAD. Malang.

Corebima, A. D. 2009. Jadikan Peserta Didik Pebelajar Mandiri. Makalah. Disampaikan pada seminar di UNM pada tanggal 19 Desember 2009.

Corebima, A. D. 2010. Berdayakan Keterampilan Selama Pembelajaran Sains Demi Masa Depan Kita Makalah. Disampaikan pada seminar Nasional Sains di Uiversitas Negeri Surabaya pada tanggal 16 Januari 2010.

Dasoete, A. 2001. Off-line Metacognition in Children with Mathematics Learning Disabilities Faculteid Psychologies en Pedagogiche Wetens Chapens. Universited Gent.

(http://acchieve.ugnet.be/retrievel/917/801 001505476.pdf, diakses tanggal 22 September 2013.

Djiwandono, S. E.W., 2006. Psikologi Pendidikan. Jakarta: Gramedia. 
Livingston, J.A. 1997. Metacognition: An Overview. Online),

(http://www.gse. bufallo.edu./fas/shuell/cep564/met acog.htm.diakses 23 jul 2013)

Malone, K.I. 2008. Correlation among Knowledge Structure, Force Concept Inventory and Problem Solving Ability. Physics Education Research. (online) 4 (2):1-15 (http//www.prstper.aps.orgpdfPRS TPERv4i2e020107) . Diakses 23 September 2013.

Mesaros, P.,M. Mesarosova., L. Mesarosova. 2012. Learning to Learn Competency, Metacognitive Learning Strategies and Academic Self Concept of University Students. International Journal of Arts and Sciences. CD - ROM. ISSN: 1944 - 6934: (Online) 5(2) 489-497.. Diakses 13 September $2013 . \quad$ (http://www.gse. Bufallo.edu./fas/shuell/cep564/ learning.htm.

Miranda, Yula. 2010. Dampak Pembelajaran Metakognitif dengan Strategi Koperatif terhadap Kemampuan Metakognitif Siswa dana Mata Pelajaran Biologi di SMA Palangka Raya. Jurnal Penelitian Kependidikan. No 2. Oktober 2010.

Nur, Muhammad. 2004. Teori-teori Perkembangan Kognitif. Edisi 2. Surabaya: Universitas Negeri Surabaya.

O’Neil Jr, H.F., and Brown, R.S. 1997. Differential Effects of question Formats in Math assesment on Metacognition and Affect. Los Angeles: CRESST-CSE University of California.

Pintrich, P.R. 2002. The Role of Metacognitive Knowledge in
Learning, Teaching and Assessing. Teori into Practice. (Online) 41 (4):

219-225

(http//www.each.usp.brcmappingp dfedmxta10.pdf). Diakses 23 September 2013.

Purwanto, G. 2007. Psikologi Pendidikan. Bandung: PT Rosda Karya.

Scraw, G., \& Dennison, R.S. 1994. Assessing Metacognitve Awareness. Contemporary Educational Psychology, 19. $460-$ 475.

Weiner, F. E \& Kluwe, R. H. 1978. Metacognition, Motivation and Understanding. Hillsdale. New Jersey: Lawrence Erlbaum Associates Publishers.

Winkel, W.S. 1997. Psikologi Pendidikan dan Evaluasi Belajar. Jakarta: Gramedia. 